\title{
Does Motivation Impact on Employee Performance? A Study on Non-Banking Financial Institutions of Bangladesh
}

\author{
Fatema Sultana (Corresponding Author) \\ Assistant Professor \\ Department of Management \\ Jashore University of Science and Technology \\ Jashore-7408, Bangladesh. \\ E-mail: fatema_mgt@just.edu.bd \\ Rashedul Islam \\ Lecturer \\ Department of Business Administration \\ City University, Dhaka, Bangladesh.
}

S.M. Yusuf Ali

Assistant Professor

Department of Management

Bangamata Sheikh Fojilatunnesa Mujib Science and Technology University

Melandha, Jamalpur

Received: Sep. 20, 2020 Accepted: Jul. 26, 2021 Online published: Aug. 3, 2021

doi:10.5296/ijhrs.v11i3.17708 URL: https://doi.org/10.5296/ijhrs.v11i3.17708

\begin{abstract}
The success of any organization mainly depends on employee performance as it leads to the organization's productivity and profitability. To enhance employee performance or let
\end{abstract}


employees' perform more following their ability, organizations need to motivate their employees. The non-banking financial institutes (NBFIs) have been contributing toward expanding both the quality and amount of monetary administrations and moderating the omissions of existing money-related intermediation to meet the developing needs of various sorts of interest in the nation. This research paper aimed to find out the relationship of motivation and how it impacts employees' performance at non-banking financial institutes of Bangladesh. The focus was on analyzing the motivation theory of Herzberg's two-factor theory. For this reason, a quantitative method was used in order to collect data. Two hundred data were collected from non-banking financial institutes from Dhaka city of Bangladesh. A structured questionnaire was formed includes two-part one is a biographical part, and another was variables-based questions. The Descriptive analysis includes mean, standard deviation, frequency distribution, and percentages; moreover, this Correlation and multi regression analysis are applied to determine the relationship and effects of motivation and employees' performance. The results of this research are positive and significant relations between employee motivation and employees' performance at the non-banking financial institutes of Bangladesh.

Keywords: non-banking financial institutes, motivation, Herzberg's two-factor theory, employees' performance

\section{Introduction}

Employees are the lifeblood of any organization. When an organization wants to improve its productivity and performance, it must concentrate on its personnel. Employees can be compared to the blood cells of an organization, therefore it's important to make sure they're performing to their full potential. The organization must focus on them in order to accelerate their performance in order to achieve the organization's goal; consequently, motivation can be used as a tool to help them improve their behavior and performance. Giving the correct combination of instruction to an organization's employees is what motivates them. They wanted motivation; they needed resources and rewards to inspire and motivate them to work in the way that one wishes them to. In today's competitive environment, firms place a premium on the management of Human Resources. A good Human Resources manager is capable of efficiently managing his employees. In this situation, motivational tools are the most effective. It's important to remember that employees aren't exclusively motivated by money, and that employee conduct is tied to their attitudes. Business companies are confronting ever-increasing hurdles in terms of employee dedication, engagement, belief, recruiting, and retention in today's competitive market. Employees at a variety of non-profit organizations are extremely committed to their work. Employees who are motivated are more likely to be productive than those who are not motivated. If an employee is satisfied and pleased, he or she will perform well at work, and the results will be as expected; on the other hand, a motivated employee will easily motivate other employees at work. Employee Job performance management is the process through which managers ensure that all of their employees' actions and outputs are in line with the organization's objectives. As a result, it is the organization's top priority to guarantee that motivating tools are in place to encourage initiative and boost employees' efforts, resulting in improved performance and excellent 
service delivery.

In order to attain high output and employee happiness, which leads to the firm's overall growth, employee motivation is vital in any organization. Motivation, according to Golembiewski (2003), refers to an organization's willingness to pursue a given goal, and it requires identifying the types and locations of the variables that produce that readiness. Kelly (2004) believes that motivation is about the factors that keep and change the direction, quality, and intensity of conduct, whereas Hoy believes that motivation is about the forces that keep and change the direction, quality, and intensity of behavior. Miskel (2007) defines employee motivation as "the complex causes, drives, demands, stress states, or other mechanisms that launch and maintain voluntary behavior targeted at accomplishing personal goals." Whetten and Cameron (2001) define employee performance as the level of an individual's work achievement after exerting effort. On the other hand, lgen (2001) performance refers to all operations involving individual employees in an organization. In order to attain goals, it is dependent on a performer's level of involvement and employee behavior in work scenarios. According to Lawler (2007), employee performance is concerned not just with what employees do, but also with how they achieve it. Appropriate motivation or the effective application of information, abilities, and talents to compete can lead to high levels of performance. Millions of people in Bangladesh rely on the non-banking financial industry for day-to-day activities such as delivering services, changing how people live in modern society, service innovation, and quality services, to name a few. Employers must encourage employees to reach high levels of performance in order for them to deliver all of these services (Coombes, 2010). It is undeniable that there is a link between employee motivation and performance. Motivation is a psychological characteristic that leads employees' behavior toward an organization's desired goal and allows them to positively contribute to improving performance. Institutional performance results in a more motivated staff with a desire to improve productivity, quality, quantity, dedication, and drive. As a result, the researchers are particularly interested in determining the relationship between employee motivation and work performance, with a focus on non-banking financial firms in Bangladesh.

\subsection{Significance of the Study}

For its own growth and survival, the organization must motivate its people. In our rapidly changing workplaces, motivated employees are essential. Because we are still a developing country, it is critical that our economy is well-represented and that we can exert our maximum effort in work environments, so we must assess where we are now in terms of employee motivation and what else we must do to ensure more proficient performance from our employees. We must also compare ourselves to others to see where we stand in terms of individual benefits. As a result, the importance of this research is clear. It's also crucial to consider employee psychology and expectations so that upper management may provide them with more and more benefits.

\subsection{Objectives of the Study}

The study's objectives are to find out how motivation impact on employees performance of non-banking financial institutions of Bangladesh. The specific objectives of the study are as 
follows:

1. To provide a theoretical background of motivations.

2. To assess the relationship between motivation and employee performance.

3. To examine the impact of motivation on employees' performance.

\section{Literature Review}

Motivated employees, according to Robison (2010), are less stressed, enjoy their work, and have better physical and mental health as a result. Motivated workers are also more loyal to their companies and show less insubordination and unhappiness. They're also more creative, imaginative, and attentive to clients, all of which help the institution succeed in the long run (MAN forum) (2009). They can generate high-quality work with increased or enhanced efficiency and productivity, resulting in higher revenues (Boundless 2017). (Matthew, Grawhich \& Barber 2009). Employees who are more motivated are more likely to contribute more, and as a result, the organization will be more profitable and successful (MSG Experts 2017).

Burney et al. (1991) discovered that employee performance is influenced by their basic abilities on the one hand, and the level of motivation displayed by each individual on the other. Motivation is an internal or external factor that motivates someone to do something in exchange for a reward.

Many people are talking about motivation these days, as well as the relationship between employee productivity and corporate productivity. Motivation will lead to the organization's personnel or employees taking their obligations and obligations seriously (Azar \& Shafighi, 2013). Attractive Salaries or Bonuses are a valuable tool for improving employee performance and raising the productivity of a firm (MUOGBO, 2013).

The role of motivation in performance can be summarized in the following formula:

\section{Performance $=$ Ability $\mathbf{x}$ Understanding of the task $\mathbf{x}$ Motivation $\mathbf{x}$ Environment .}

\subsection{Motivation}

The word "motivation" is derived from the word "motive," which relates to a person's needs, goals, and desires, according to Chaudhary \& Sharma (2012). As a result, "employee motivation" refers to the process through which an organization drives its employees to fulfill organizational goals through awards, bonuses, and other incentives. Motivation affects outcomes such as productivity, performance, and persistence, according to Grant's (2008) employee motivation research (Grant, 2008). Motivated employees are more oriented toward autonomy and independence, and are more self-driven than less motivated employees, according to studies (Ryan and Deci, 2000; Thomas, 2002, as stated in Grant, 2008). As a result, they are more responsibly taking advantage of growing opportunities. Employee engagement with their work and jobs is also stronger among motivated employees than among those who are less motivated (Guay et al., 2000; Vansteenkiste et al., 2007). 
Guay et al. (2010) argue that motivation refers to the core activity of driving. Motivation is an internal sensation that encourages an individual to engage in a specific activity, and it is believed that motivation may be seen from two perspectives (Spector, 2003). For a organization or management to treasure a way to encourage their employees, motivation is critical. When employees understand that their opinions are respected, they develop a sense of belonging, which can help inspire them. The incentive always meets the workers' demands and expectations, and the individuals repay it by working hard and being honest. The organization's major goal is to classify the requirements and wishes of the employees and respond to them using the most basic way of all organizations to gain their commitment (Surbhi, S. 2012).

Motivation can be both intrinsic and extrinsic, according to Hitt, Esser, and Marriott (2002). Extrinsic motivation refers to behavior that is impacted by external rewards. Extrinsic or external rewards include praise or positive feedback, money, and the absence of punishment. According to Deci (2009), intrinsic motivation is the desire to accomplish something solely for the joy of doing it. Intrinsic elements include work interest, recognition, growth, and achievement, according to Hagedoorn \& Van Yperen (2003).

Intrinsic motivation stems from a drive to learn new things and push oneself to new limits. It's the desire to study, obtain information, and discover one's own self-worth and ability (Ryan 2000). Intrinsic motivation, according to Guay et al. (2010), refers to motivation that is fueled by individual attention, is pleasurable, and is usually distinct from extrinsic motivation, which is fuelled by reinforcement.

Extrinsic motivation, on the other hand, relates to doing tasks in order to attain the desired results. Both internal and external variables can contribute to extrinsic motivation. The majority of the time, however, it is caused by external forces rather than internal ones (e.g. individual itself). Extrinsic motivation is created by a variety of circumstances, including contests, appraisals, external incentives, and punishment (Dewani 2013).

\subsection{Employee Performance}

According to Koontz et al. (1990), employee performance refers to employees' efficiency and effectiveness in achieving business goals and objectives. He went on to suggest that absenteeism, report quality, and the time spent reporting for and departing duty can all be utilized to assess employee performance. An employee's performance is influenced by what he or she does and does not do. Individual performance could not be validated, according to the findings of a study on individual performance conducted by Yang (2008). Similarly, he claims that if employee performance is obvious, firms can use direct bonuses and awards based on individual success (Yang, 2008; Rizwan et al., 2013).

According to Landy (1985) and other studies on employee efficiency, persons who are content with their jobs have higher work performance and consequently more job satisfaction than those who are dissatisfied with their jobs. Because highly satisfied and happy employees perform better, the business was able to attain its targeted goals and objectives with greater employee participation. Performance is critical for the organization or firm workers to make 
every effort to support marginal performers. However, if the organization is unable to adequately motivate its employees, it will fail (Ahmad, 2012).

Ability, working environment, and motivation all have an impact on employee performance. Employees must be involved in order for creativity to be implemented (Liu, C.H, 2013).

Individual performance is defined by the quantity and quality of output, the willingness to put up effort, the ability to be accommodating and cooperative, and the timeliness of outcomes. Individuals' performance is largely influenced by motivation, because if employees are satisfied or driven, they will put in more effort at work, resulting in improved performance (Azar \& Shafighi, 2013).

Employees need rewards and incentives to turn their displeasure into joy. In his study, Mehmod (2013) also states that when workers are satisfied, they would execute their jobs, express their importance, and endeavor to do better work, resulting in good performance. Reasonable salaries are also an app, and they play a vital role in enhancing worker performance and increasing production. Individual performance refers to the typical actions that people exhibit in connection with their jobs (Rashidpoor, 2000).

\subsection{Impact of Motivation on Employees' Performance}

Motivating employees is the most prevalent strategy used by managers to improve performance effectiveness. As a result, motivation aids an organization's achievement of its objectives because motivated people are more likely to work toward them. The age-old carrot-and-stick approach does not work in today's climate, and managers must reinvent how they encourage people, achieve desired results, and reward personnel (Forson, 2012).

Performance appraisal, employee happiness, training and development, job security, salary, organizational structure, and other factors influence employee motivation and performance. Employee motivation is heavily influenced by employee performance; in order to get the desired results, a firm must establish successful motivation programs (Dobre, 2013).

The actual talents of the employees have a critical influence on the quality of the performance; there is a requirement for employees' attention by inspiring them. According to research, financial motivation has become a primary concern in every organization. Managers and other managerial concern bodies believe that by giving money or financial incentives to employees, their efficiency can be increased; however, with financial benefits or incentives, nonfinancial incentives are required so that employees can be satisfied with their jobs. 2014 (Ehimen, Mordi, \& Ajonbadi).

In Somalia, a study looked into the impact of motivation on employee performance in telecommunications enterprises. Employee motivation has an impact on employee performance in Somalia's telecommunication companies, according to the findings of the study. All employees should be motivated, according to the study, in order to ensure that they are retained and that their performance improves. Overall organizational productivity and effectiveness can be improved in this way (Sh. Yusuf \& GICHINGA,2016). Another study investigated what factors influence employee motivation in Pakistan, as well as the extent to 
which motivation influences employee performance. Employee motivation and performance have a significant and favorable relationship, according to this study. Shahzadi and colleagues (2014).

Money is believed to be the best motivator to any human, according to Jan Ketil Arnulf's article "Money as a Motivator" on Fudan University School of Management (2014). Is money, however, the best and exclusive motivator? Or have any of the other motivators overtaken the money motivator? To put it another way, we labor for money plus a variety of other reasons, including achievement, recognition, progression, growth, responsibility, and the work itself (Herzberg 1987).

Praise is one of the most powerful strategies for motivating others. The most popular strategies of encouraging employees are to express gratitude and admire them. It means a lot to look into the eyes of an employee in front of others and express gratitude (Salasiah, Zainab, Rosmawati, Ermy, 2010). Employees who feel appreciated and praised by their superiors are more likely to work better, which leads to increased corporate productivity (Salasiah, Zainab, Rosmawati, Ermy, 2010). As a result, the more managers compliment their employees, the easier the jobs will be and the more productive they will be. David, Louis, and Micheal (David, Louis, and Micheal, 2004).

Employees work harder when they are recognized and rewarded for their efforts toward work and duties, according to Pinar (2011); they do their best to demonstrate their skill, talents, and abilities. Employees who are valued and recognized are more confident in their abilities to contribute. It also ensures a positive, productive, and forward-thinking work environment. Thanking people as a kind of recognition will help the organization succeed (David,Louis, Micheal,2004). However, it is important to keep in mind that employee recognition as a motivator might vary, as one individual may experience an increase in work productivity after being recognized, while another may experience the reverse. (Heaflthield 2017).

Employees who are given a new role with significant responsibilities are driven to work harder because they realize that their efforts will yield great results, and they will be recognized as a result (David Louis, Micheal, 2004). ,

Most researchers concluded that we need leadership, not management, to encourage personnel and attain the desired results. As a result, being a leader rather than a manager is more vital for motivating employees (Yongsun, Barbara, and Christy, 2002).

Advancement as a motivator refers to the possibility of being promoted to a better position, earning a larger pay, and receiving additional perks from the firm. Understanding each employee's demands and aiding them in attaining the pleased drivers is also a strategy to inspire staff (Lipman 2014).

Growth incentive is broader than merely getting a promotion or a better income and benefits package. Employees who are energetic, eager, determined, and most importantly, ambitious are desirable. As a result, giving and encouraging growth motivation for employees is an important approach of enhancing motivation (Lipman 2014). 


\section{Macrothink}

International Journal of Human Resource Studies

ISSN 2162-3058

2021, Vol. 11, No. 3

Employee motivation is also influenced by the task itself. A satisfied employee may stay, but if you truly want to motivate your employees, give them fascinating stuff to do and allow them to participate in it. This entails fostering strong work cultures, supporting creative thinking and innovation, and preventing unpleasant, unfair, and powerless workplaces (Landrum 2015).

Mulwa (2003) investigated employee performance in Kenyan public auditing organizations. He delves into many motivation theories, such as Abraham Maslow's hierarchy of needs, Hertzberg's two-factor theories, and Adams' equity theory. The study found that employee motivation is critical to an organization's productivity, profitability, and long-term viability, as employees are its drivers and lifeblood.

For developing countries like Bangladesh, the concept of motivation is not new. However, just a few research have been conducted on employee motivation and how it affects employee performance in order to accelerate organizational success. As a result, the researchers attempted to conduct this study in order to determine the relationship between employee motivation and performance in the sector of no banking financial institutions in Bangladesh. The researchers hope and expect that this study will meet a current requirement for organizations in the competitive market to improve their employees' performance through suitable motivation in order to compete with their competitors.

\section{Conceptual Framework}

Reviewing the previous literature, the research model is conceptualized as the following way:

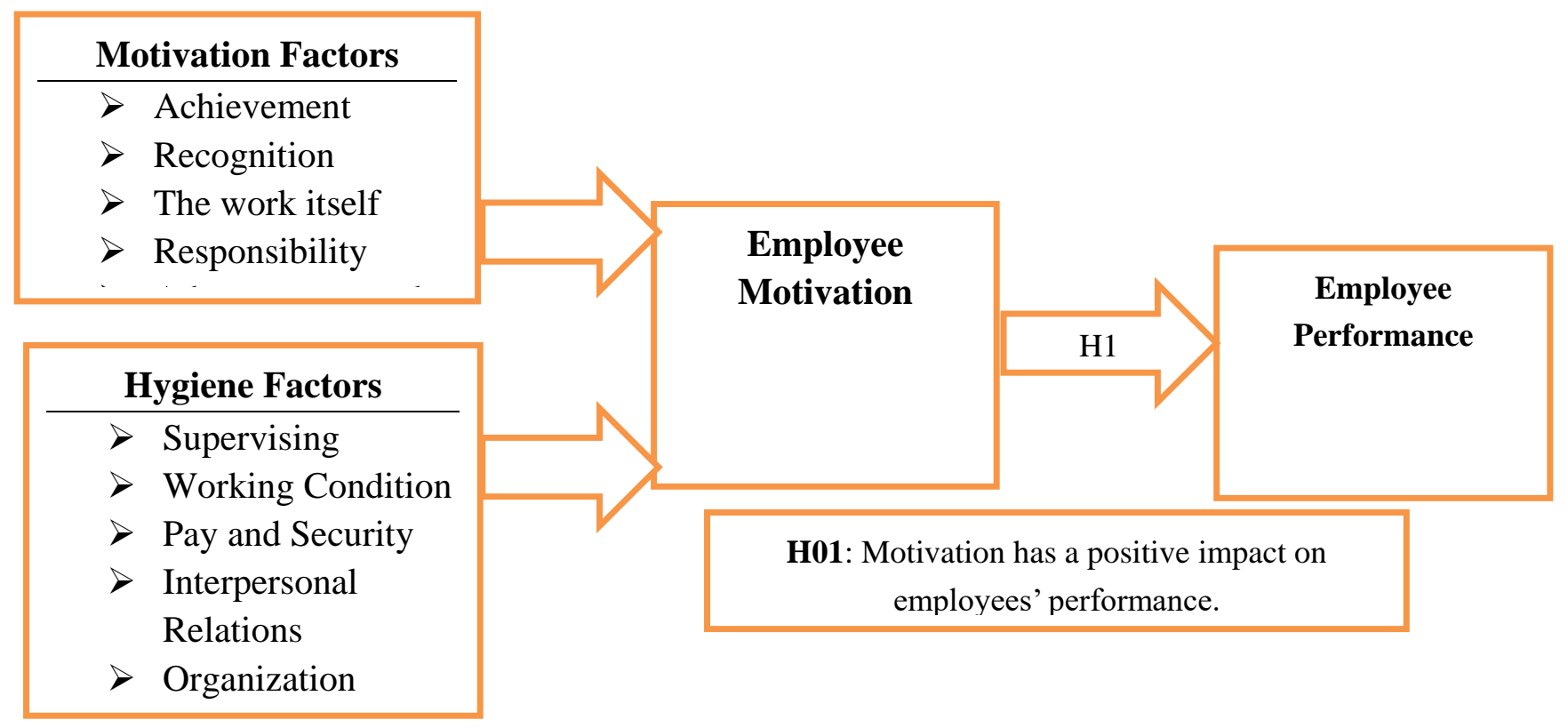

Figure 1. A research model for employee motivation and employee performance

\section{Hypothesis development}

H0: Motivation has a positive impact on employees' performance. 


\section{Research Methodology}

\subsection{Data Collection and Analysis}

The research is mostly descriptive, though there is some quantitative analysis based on source data. The descriptive study was chosen because, according to Mugenda (2003), "descriptive survey design helps the researchers acquire, synthesize, present, and evaluate information for clarification." The researchers first reviewed several publications from various databases relevant to employee motivation and its effects on employee performance in order to formulate the topic and construct a study model. Furthermore, the researchers gathered primary data using a well-structured questionnaire and conducted an online survey utilizing Google forms employing both face-to-face interview methods and an online survey. The questionnaire was separated into two sections: biographical information for responders and variable-based questions. For the examined variables, the questionnaire was designed using a 5-point Likert scale (ranging from 1-strongly disagree to 5-strongly agree), whilst the biographical questions were divided into distinct groups based on the nature of the questions. Finally, using IBM-SPSS 23 version, the acquired data was processed and displayed in various tabulations.

\subsection{Study area}

The researchers have conducted the current study in the non-banking financial institutions considering that it is one of the most booming sectors that generate a high level of national income, impacting national GDP in Bangladesh. The study mainly covers the non-banking financial institutions located and operated in the capital Dhaka and the different districts through their district branches. Due to the location convenience and limitation of time, the researchers have conducted the study in Dhaka city and near to Dhaka city.

\subsection{Sample Size Determination and Used}

The authors used Cochran's (1963) recommendations to determine sample size: 'when there is a large population, but the variability in the proportion is unknown, the sample size should be considered at least as 400, 200, and 100 accordingly at the 5 percent, 7 percent, and 10 percent precision levels.' In light of Cochran's (1963) arguments, the researchers opted to collect data by sending a questionnaire to 300 respondents from twenty-five non-banking financial institutions, with ten sample respondents from each institution. In reality, the researchers were able to collect data from a total of 223 sample respondents, which were chosen randomly; after collecting the data, about 23 sets of questionnaires were found somewhat incomplete or inconsistent, and we decided to drop those questionnaires. Finally, 200 sets of questionnaires were used for this study which indicates the response rate is about $91.03 \%$. By the way, the researchers have considered $7 \%$ percent precision level and used 200 samples (suggested at least 200) for the present study. Among the respondents, 56\% were from mid-level and $26 \%$ operation level, whereas $18 \%$ were from the managerial level or top level.

\subsection{Variables and Measures}




\section{Macrothink}

International Journal of Human Resource Studies

ISSN 2162-3058

2021, Vol. 11, No. 3

The researchers have measured all the considered variable using self-developed questions considering different conventional means. A total of 14-questions were used for two variables; among those, eight questions for employee motivation and six questions for employee performance. To develop a questionnaire for the independent variables, employee motivation with other sub-variables like motivator's factors and hygiene factors were combined. Intrinsic and extrinsic motivation factors were considered under motivating employees. Besides, employee performance was considered here as mediating variable and dependent variable accordingly. However, the respondents' age, sex, education, job designation, experience, and scale of business operations were considered as control variables for the study. Finally, the following linear regression model was used for the study.

The statistical model shows the mathematical relationship between the independent variable motivation and dependent variable employee performance. The model was useful to the study as it enabled the researcher to estimate the independent variables' coefficients and establish the causal effect relationship between motivation and employee performance.

Here,

$$
\mathrm{Y}=\beta 0+\beta 1 \mathrm{X} 1+\mathrm{e}
$$

Where $\mathrm{Y}$ is the dependent variable (employee performance), $\mathrm{X} 1$ :employee motivation, $\beta 1$ : is the coefficients of the independent variable, $\beta 0$ : intercept term, and e: Error term.

\section{Findings}

Male participants account for 78.5 percent of the data collected, while female participants account for 21.5 percent. Twenty percent of the participants were between the ages of 20 and $30,37.5$ percent were between the ages of 31 and 40, 26.5 percent were between the ages of 40 and 50, and 16 percent were 51 and up. According to the results of this poll, 18.5 percent completed their diploma or comparable degree, 47 percent graduated, and the remaining $26 \%$ completed their post-graduation, and only 8.5 percent obtained a higher degree. Sixty-six percent of the respondents were from the mid-level and 26 percent from the operations level, while 18 percent were from the managerial or top-level. Of total respondents, $24.4 \%$ are working in these institutions for less than five years, $45 \%$ have 5-10 years of experience, and among the rest of the respondents, $19.5 \%$ have $10-15$ years, and the rest of the $11 \%$ have more than 15 years of experiences. Thirty percent of the participants earned between Tk. 20,000 and 35,000; 45 percent earned between Tk. 35,001 and 50,000; 15\% percent earned between Tk. 51000 and Tk. 75,000; and 10 percent earned more than Tk.75001 and above per month. 
Table 1. Demographic characteristics of respondents

\begin{tabular}{|lccc|}
\hline & Variables & $\mathbf{N}$ & Percentage(\%) \\
\hline \multirow{3}{*}{ Gender } & Male & 157 & $78.5 \%$ \\
& Female & 43 & $21.5 \%$ \\
Age & $20-30$ & 40 & $20 \%$ \\
Education & $31-40$ & 75 & $37.5 \%$ \\
& $41-50$ & 53 & $26.5 \%$ \\
& $51+$ & 32 & $16 \%$ \\
Working & Diploma/ Under Graduate & 37 & $18.5 \%$ \\
Position & Graduates & 94 & $47 \%$ \\
& Post Graduates & 52 & $26 \%$ \\
Experience & Others & 17 & $08.5 \%$ \\
& Operational Level & 112 & $56 \%$ \\
& Mid-Level & 52 & $26 \%$ \\
Income & Top Level & 36 & $18 \%$ \\
& $<5$ & 49 & $24.5 \%$ \\
& $5-10$ & 90 & $45 \%$ \\
& $10-15$ & 39 & $19.5 \%$ \\
& $15+$ & 22 & $11 \%$ \\
& $20000-35000$ & 60 & $30 \%$ \\
& $35001-50000$ & 90 & $45 \%$ \\
& $50001-75000$ & 30 & $15 \%$ \\
& $75000+$ & 20 & $10 \%$ \\
\hline
\end{tabular}

\section{Descriptive Statistics:}

Table 2. Descriptive Statistics

\begin{tabular}{|lllll|}
\hline & $\mathrm{N}$ & Mean & Std. Deviation & Variance \\
\hline Employee Motivation & 200 & 3.35 & 0.689 & 0.475 \\
Employee Performance & 200 & 3.72 & 0.694 & 0.482 \\
Valid N (List wise) & 200 & & & \\
\hline
\end{tabular}

The descriptive statistics illustrate that all the average (mean) values are higher than 3.0 (highest point is 5.0), where the standard deviation is \pm 0.689 to 0.694 .

Table 3. Alpha Coefficient of Reliability on variables

\begin{tabular}{|lccc|}
\hline Reliability Statistics & & & \\
\hline & Cronbach's Alpha & $\begin{array}{c}\text { Cronbach's Alpha Based on } \\
\text { Standardized Items }\end{array}$ & N of Items \\
\hline Employee Motivation & 0.776 & 0.774 & 8 \\
Employee Performance & 0.745 & 0.746 & 6 \\
Valid N (List wise) & 200 & & \\
\hline
\end{tabular}

As indicated in Table 3, Cronbach's alpha values for all variables vary from.745 to.776, obtaining the lowest allowed level of coefficient alpha above 0.70. Pallant (2007; Pallant, 
2007; Pallant, 2007; Pallant, 2007; Pal According to Kothari, validity can be tested using expert opinion and educated judgment (2004). The study employed Cronbach Alpha, which is a measure of internal consistency. Cronbach Alpha was more than 0.7 for all independent factors. The independent variable, motivation, has the highest Cronbach's alpha of.776, followed by employee performance with a Cronbach's alpha of.745. All of these variables have a value greater than.70, which is considered satisfactory. So the results show that all the variables are reliable for the data collection.

Table 4. Correlation of the variables

\begin{tabular}{|ll|c|c|}
\hline \multicolumn{2}{|l|}{ Correlations } & Employee Motivation & Employee Performance \\
\hline Employee Motivation & Pearson Correlation & 1 & $.578^{* *}$ \\
& Sig. (2-tailed) & & .000 \\
& $\mathrm{~N}$ & 200 & 200 \\
Employee Performance & Pearson Correlation & $.578^{* *}$ & 1 \\
& Sig. (2-tailed) & .000 & 200 \\
& $\mathrm{~N}$ & 200 & \\
\hline **. Correlation is significant at the 0.01 level (2-tailed). & & \\
\hline
\end{tabular}

** Correlation is significant at the 0.01 level (2-tailed).Independent variables: Employee Motivation, Dependent variable: Employee Performance.

The Pearson's coefficient correlation was used to determine the degree and direction of the linear relationship between variables, namely Motivation and Employee Performance. The correlation test revealed that there is a positive association between motivation and employee performance, as shown in Table 4. This association has a strength of 57.8 percent. As a result, there is a high $57.8 \%$ positive association between motivation and employee performance. Motivation is found to be positively connected with employee performance, with a $p$-value of 0.000 , which is statistically significant at $1 \%$. Hence, it could be concluded that the higher the employee motivation higher the employee performance, and the higher the job satisfaction.

\begin{tabular}{|l|c|c|c|c|c|c|c|c|c|}
\hline \multicolumn{2}{|l|}{ Model Summary } \\
\hline
\end{tabular}

\begin{tabular}{|c|c|c|c|c|c|c|c|}
\hline Coefficients & & & & & & & \\
\hline & Unsta & rdized & Standardized & & & $95.0 \%$ & Confidence \\
\hline & Coeff & & Coefficients & & & Interva & r B \\
\hline Model & B & Std. Error & Beta & $\mathrm{t}$ & Sig. & $\begin{array}{l}\text { Lower } \\
\text { Bound }\end{array}$ & $\begin{array}{l}\text { Upper } \\
\text { Bound }\end{array}$ \\
\hline $1 \quad$ (Constant) & 2.005 & .229 & & 8.737 & .000 & 1.550 & 2.459 \\
\hline
\end{tabular}




\begin{tabular}{|l|l|l|l|l|l|l|l|l|}
\hline $\begin{array}{l}\text { Employee } \\
\text { Motivation }\end{array}$ & .582 & .076 & .578 & 7.691 & .000 & .432 & .732 \\
\hline
\end{tabular}

Table 5. Summary of Regression results of Motivation and Employee Performance

\begin{tabular}{|llll|}
\hline Independent variable & \multicolumn{1}{c}{$\begin{array}{c}\text { Unstandardized coefficients } \\
\text { (B) }\end{array}$} & $\begin{array}{c}\text { Standardized coefficients } \\
\text { (Beta, } \beta)\end{array}$ & Sig. \\
\hline (constant) & 2.005 & .578 & .000 \\
Motivation & .582 & & .000 \\
R & $.578^{\mathrm{a}}$ & & \\
R square (R2) & .334 & & \\
\hline Adjusted R square & .328 & & \\
\hline
\end{tabular}

a. predictors: (constant), Motivation

b. dependent variable Employee Performance

The impact of motivation on employee performance was investigated using regression analysis. The regression results yielded a $\mathrm{R}$ square value of 0.334 , as shown in table 5 . The coefficient of connection explains that the value of $\mathrm{R}$ square is 0.334 , implying that motivation accounted for 33.4 percent of the variance in employee performance. The variable that contributes to the dependent variable is indicated by the Beta $(\beta)$ value of standardized coefficients. Employee motivation has a favorable impact on employee performance $(=0.578$, p-value less than 0.01), according to these studies. This means that employee motivation in Bangladesh's non-banking financial institutions might have a favorable impact on their performance. If upper management concentrates on motivation, the organization or firm can improve employee performance and achieve the intended goals and objectives. As a result, our null hypothesis, that motivation has a positive and significant effect on employee performance, is accepted.

\section{Assessment of the Hypothesis}

Ho1: There is a positive relationship between Motivation and Employee Performance.

\section{Recommendations for Management:}

The findings of this study can be applied effectively and efficiently to improve the current state of motivation in our country's non-banking financial institutions. Employee motivation is a simple and dynamic chore that necessitates more than an annual review or a few comments in a person's personnel file. Based on the research and poll done above, the following recommendations can be put into effect.

The study can also be used to bring a clear idea concerning how to implement different motivational theories of motivation into the practical field of work to enhance employee performance. 


\section{Macrothink}

International Journal of Human Resource Studies ISSN 2162-3058 2021, Vol. 11, No. 3

On the basis of the result of this study, the organization can get an overview of the real scenario if they require taking steps regarding motivation.

The results can be used to compare between the present scenario of motivation, and the optimum rate of motivation should be applied to attain organizational goals most effectively.

To inspire these sectors to enforce more motivational tools in order to achieve more successes.

\section{Conclusion}

Based on the preceding research and the respondents' responses to the questionnaire, the researcher came to the conclusion that motivation does have a major impact on employee performance. We can plainly deduce from the information supplied above that the elements considered during the review pragmatically dominate employees' desire to perform and achieve the particular organization's goals. Salary, monetary incentives, and compensation package are factors considered under extrinsic motivation; work environment, responsibility, promotion, and recognition and appreciation for work done are factors considered under motivation and employee performance; and relationship with superiors, peers, and job security are factors considered under Relationships and security.

\section{References}

Ahmad, M. Wasay, E., \& Malik, S. (2012). Impact of Employee Motivation on Customer Satisfaction: Study of Airline Industry in Pakistan: Interdisciplinary Journal of Contemporary Research in Business. Institute of Interdisciplinary Business Research, 4(6).

Azar, M., \& Shafighi, A. (2013). The Effect of Work Motivation on Employees' Job Performance. International Journal of Academic Research in Business and Social Sciences, 3(9). https://doi.org/10.6007/IJARBSS/v3-i9/231

Barney, J. (1991). Firm resources and sustained competitive advantage, J. Management, 17, 99-120. https://doi.org/10.1177/014920639101700108

Boundless Management. (2017). Employee Needs and Motivation. Accessed 3.9.2017. https://www.boundless.com/management/textbooks/boundlessmanagement-textbook/organiza tional-behavior-5/employee-needs-andmotivation-46/maslow-s-hierarchy-of-needs-171-7621/

Coombes, J. (2012). Positive effects of rewards and performance standards on intrinsic motivation. The Psychological Record, 53(4), 4-10.

Chowdhury, M. S. (2007). Enhancing Motivation and Work Performance of the Salespeople: The Impact of Supervisors' Behavior. African Journal of Business Management, 1(9), 238-243.

David, S., Louis, A. M., Micheal, I. M. (2004). Why your employees are losing motivation. Working Knowledge for business leaders, 4(10), pp. 1-4. 
Deci, E. L. (2009). The path taken: consequences of attaining intrinsic and extrinsic aspirations in post-college life. J. Research in Personality, 43, 291-306. https://doi.org/10.1016/j.jrp.2008.09.001

Deci, E. L., \& Ryan, R. M. (2000). The „whate and „why ${ }^{\text {ee }}$ of goal pursuits: human needs and theself-determination of behaviour", Pshychological Inquiry, 11(4), 227-68. Lovelock, C.H. (1996), Services Marketing, Prentice-Hall.

$\begin{array}{lllll}\text { Dewani, } & \text { V. } & \text { Motivation. } & \text { 3.9.2017. }\end{array}$ https://www.slideshare.net/vijaydewani7/motivation-15959567.

Golembiewski, R. T. (2003). Motivation. In Carl Heyel (Ed.), the Encyclopedia of Management 2nd. New York: Van Nostrand Reinhold. Government.

Guay, F., Chanal, J., Ratelle, C. F., Marsh, H. W., Larose, S., \& Boivin, M. (2010).Intrinsic, identified, and controlled types of motivation for school subjects in young elementary school children. British Journal of Educational Psychology, 80(4), 711-735. https://doi.org/10.1348/000709910X499084

Hagedoorn, V. Y. (2003). Designing motivating jobs. Institute of work psychology. University of Groningen, Netherlands.

Heathfield, S. M. (2017). What People Want from Work: Motivation. Accessed 3.9.2017. https://www.thebalance.com/what-people-want-from-work-motivation-1919051.

Herzberg, F. (1987). One More Time: How Do You Motivate Employees? Harvard Business Review, 65(5).

Hitt, D. A., Esser, J. K., Marott, R. G. (2002). Effects of delayed rewards and task. J. Special Issue of Organizational Behaviour and Human Decision Processes, 73-484.

Hoy, W., \& Miskel, C. (2007). Educational Administration: Theory, Research, and Practice. New York: Random House.

Igen, J. (2001). Teacher data in secondary schools in Ekiti State. In: Speech delivered by the Permanent Secretary at the Senior Staff Seminar, Ministry of Education, Ado Ekiti. pp. 1-9.

Kelly, J. (2004). Organizational Behaviour. Homewood: Richard D. Irwin.

Koontz, H. (1990). Essentials of management. New York, NY: The Free Press.

Landrum, S. (2015). What truly motivates employees? Accessed 3.9.2017. https://talentculture.com/what-truly-motivates-employees/

Landy, F. J. (1985). Psychology of Work Behavior. Chicago, IL: The Dorsey Press.

Lawler, E. (2007). Job design and employee motivation. Personality Psychology, 22(4), 426-435. https://doi.org/10.1111/j.1744-6570.1969.tb00343.x

Lipman, V. (2014). New Study Answers: What Motivates Employees to "Go the Extra Miles?".

Accessed

3.9.2017. 
https://www.forbes.com/sites/victorlipman/2014/11/04/what-motivatesemployeesto-go-the-extra-mile-study-offers-surprising-answer/\#77eeefa3a055.

Liu, C. H. (2013). The processes of social capital and employee creativity: empirical evidence from intraorganizational networks. The International Journal of Human Resource Management, pp: 1-17.

Man Forum (2009). What motivates you? The best motivational tips from the forum.BT mentor program, Frorida:USA.

Matthew, J. G., \& Barber, L. K. (2009). Are you Focusing both Employees and Organizational Outcomes? Organizational Health Initiative at Saint Louis University, 1-5.

Mulwa F. W. (2003). The efficacy of participatory strategic planning Approaches to organizational building.University of South Africa.SA.

Muogbo, U. (2013). The Impact of Employee Motivation On Organisational performance (A Study Of Some Selected Firms In Anambra State Nigeria). The International Journal of Engineering and Science (IJES), 2(7), 70-80.

Pinar, G. (2011). The Relationship between Reward Management System and Employee Performance with the Mediating Role of Motivation: A Quantitative Study on Global Banks. Procedia Social and Behavioral Sciences, 24(2011), 1510-1520. https://doi.org/10.1016/j.sbspro.2011.09.029

Rashidpoor, M. (2000). Correlation analysis of organizational commitment and job performance of calculating organization personnel. Unpublished M.Sc. Thesis, Governmental Management Education Center, p.180.

Rizwan, M., Shahid, M., Shafiq, H., Tabassum, S., Bari, R., \& Umer, J. (2013) Impact of Psychological Factors on Employee Turnover Intentions, International Journal of Research in Commerce. Economics and Management, 3(3), 63-69.

Robison, J. (2010). Disengagement can be really depressing, Gallup Management Journal website,published20100402, availableat:http://gmj.gallup.com/content/127100/disengagement -really-depressing.aspx,retrieved 2010-06-29.

Ryan, R. M., \& Deci, E. L. (2000). Intrinsic and Extrinsic Motivations: Classic Definitions and New Directions. Contemporary Educational Psychology, 25, 54-67. https://doi.org/10.1006/ceps.1999.1020

Salasiah, H. H., Zainab, I., Rosmawati M., Ermy, A. R. (2010). Methods of Increasing Learning Motivation among Students. Procedia Social and Behavior Science, 18(2011), 138-147. https://doi.org/10.1016/j.sbspro.2011.05.021

Shahzadi, I., Javed, A., Pirzada, S. S., Nasreen, S., \& Khanam, F. (2014). Impact of Employee Motivation on Employee Performance. European Journal of Business and Management, 6(23), 159-166. 


\section{Macrothink}

International Journal of Human Resource Studies

ISSN 2162-3058 2021, Vol. 11, No. 3

Sh. Yusuf, M. A., \& Gichinga, L. (2016). Effects of employee motivation stratedies on employee performance in telecommunication companies in Somalia:. IJRDO. Journal of Business Management, 2(9), 233-251.

Spector, P. E. (2003). Industrial and organizational psychology-Research and practice (3rd edition). New York: John Wiley \& Sons, Inc.

Surbhi, S. (2012). Effect of Motivation on employee performance and Organizational Productivity. Journal of Applied Management \& Computer Science, 1.

Vansteenkiste, M., Lens, W., \& Deci, E. L. (2006). Intrinsic versus extrinsic goal contents in self-determination theory: another look at the quality of academic motivation. Educational Psychologist, 41(1), 19-31. https://doi.org/10.1207/s15326985ep4101_4

Whetten and Cameron. (2001). Improving employee performance appraisal method through web-based appraisal support system: system development.

Yang, H. (2008). Efficiency Wages and Subjective Performance Pay. Economic Inquiry, 46(2), 179-196. https://doi.org/10.1111/j.1465-7295.2007.00069.x

Yongsun, P., Barbara, S., \& Christy, M. (2002). How to improve repatriation management: are motivations and expectations congruent between the organization and expatriates. $\begin{array}{llll}\text { International Journal of } & \text { Manpower, 23(7), }\end{array}$ https://doi.org/10.1108/01437720210450815

\section{Copyright Disclaimer}

Copyright for this article is retained by the author(s), with first publication rights granted to the journal.

This is an open-access article distributed under the terms and conditions of the Creative Commons Attribution license (http://creativecommons.org/licenses/by/4.0/). 